E. Guilley · J. P. Charpentier · N. Ayadi

G. Snakkers · G. Nepveu · B. Charrier

\title{
Decay resistance against Coriolus versicolor in Sessile oak (Quercus petraea Liebl.): analysis of the between-tree variability and correlations with extractives, tree growth and other basic wood properties
}

Received: 4 May 2004 / Published online: 2 October 2004

(C) Springer-Verlag 2004

\begin{abstract}
Weight loss due to fungus Coriolus versicolor has been measured on 614 samples according to the NF EN 113 norm. Up to eight samples were cut at breast height (two opposite radiixfour radial positions in heartwood) from 82 mature sessile oaks (Quercus petraea Liebl.) originating from contrasting regions, silvicultural schedules and site qualities in France. The following points are addressed in the paper: (i) contribution to the total variability for weight loss of the effects "tree", "position in the tree", as well as their interaction; (ii) percentage of wood samples and trees in each of the five classes of natural durability defined by the norm NF EN 350-2; (iii) test of the effects of region, silvicultural schedule and site quality on weight loss and evaluating their contribution to the total variation; and (iv) correlations at tree level between weight loss and several traits related to tree growth and
\end{abstract}

E. Guilley $(\bowtie)$

CIG, Université de Genève, 59 Route de Mon-Idée,

CH-1226 Thônex Genève, Suisse

E-mail: Edith.Guilley@cig.unige.ch·Tel.: +41-22-3056604·Fax: +41-22-3489077

J. P. Charpentier

Unité d'Amélioration, Génétique et Physiologie Forestières,

Avenue de la Pomme de Pin, BP 20619,

Centre INRA d'Orléans, F-45166, Olivet, France

N. Ayadi

Ecole Supérieure de Bois, Atlanpole BP 10605,

Rue Christian Pauc, F-44306, Nantes, France

G. Snakkers

Bureau National Interprofessionnel du Cognac,

23 allée Champs de Mars, F-16100, Cognac, France

G. Nepveu

Laboratoire d'Etude des Ressources Forêt-Bois (LERFOB),

Unité Mixte de Recherches sur la Qualité des Bois,

Centre INRA de Nancy, F-54280, Champenoux, France

B. Charrier

Sylvadour, Université de Pau et des Pays de l'Adour,

BP201-371, rue du ruisseau, 40004 Mont de Marsan, France 
basic wood properties (density, swelling, grain angle, multiseriate wood rays characteristics, extractives content). The results are discussed with a view to aid the forest manager as well as the $\log /$ wood user to take advantage of the high level of between-tree variability observed as natural durability against $C$. versicolor.

\section{Introduction}

The possibility of taking advantage of the natural durability against fungi of some woods would result in great benefits when considering the increasing pressure against the use of chemicals to protect this material. In Europe, five classes of natural durability against fungi have been defined: class 1 as "very durable", class 2 as "durable", class 3 as "moderately durable", class 4 as "poorly durable", and class 5 as "no durable" (AFNOR 1994b). These classes correspond to contrasted weight losses when exposed to fungi (AFNOR 1994a). The only European hardwood classified as "very durable to durable" (class 1 to 2) is Black locust (Robinia pseudoacacia) (AFNOR 1994b), a wood species very poorly represented in the French forest resource. When considering the hardwoods of economical significance in France, only two are classified as "durable" (class 2): Sessile and Pedunculate oaks ( $41 \%$ of the standing hardwood resource) and chestnut (8\%) (SCEES 1996). As a result, outdoor use of oak (and chestnut) is restricted.

To date, a poor number of studies are available that have investigated somewhat intensively the between-tree variability for decay resistance-Viitanen et al. (1998) on Larix sibirica, Srinivasan et al. (1999) on Larix laricina, Dumonceaud (2001) on Castanea sativa, and Freitag and Morrell (2001) on Thuja plicata - and attempted to clarify the possible reason(s) for this variability (genetics, silviculture, environment, etc.). For European oaks, only one reference has been found in this matter (Ayadi et al. 2001) which evaluated the interspecific variability for natural durability (Quercus robur versus Quercus petraea) as well as the between-tree variability in each of the two species.

The present paper investigates the between-tree variability for decay resistance against Coriolus versicolor in Sessile oak, interprets it according to the origin of the tree (region, silvicultural schedule, site quality) and correlates the decay resistance with data related to growth and basic wood properties of the corresponding trees (considerable basic data related to the growth and wood properties of the trees has been gained through previous studies). Mosedale et al. (1996) had demonstrated the lack of distinct site effect on the concentrations of ellagitanins in oak heartwood clonal groups. However, it is known that variations in content of toxic extractives may induce resistance of various woods to fungal attack (Tsoumi 1991). In this work we test whether ellagitanins concentration is strongly linked with oak wood natural durability. If the between-tree variability for natural durability against fungi is sufficiently high and controllable in oak, then it would allow the forest manager and/or the log/wood user to realistically take advantage of this variability through silvicultural control and/or $\log$ /sawn wood sorting. 


\section{Material and methods}

\section{Tree sampling}

A total of 82 mature sessile oak trees were sampled in France for the study. They originated from 48 plots (14 one-tree plots and 34 two-tree plots), sampled in five regions (Alsace, Allier, Lorraine, Orne-Sarthe, Loir-et-Cher), two silvicultural schedules (high forest, coppice with standard), and three site qualities (high, medium, poor). Table 1 presents the number of trees and plots available in each combination of silvicultural schedule, region and site quality.

The average tree characteristics were $28 \mathrm{~m}$ for total height (minimum $=17 \mathrm{~m}$; maximum $=40 \mathrm{~m}), 13.6 \mathrm{~m}$ for height of the crown base $(2.8 \mathrm{~m} ; 23.5 \mathrm{~m}), 62 \mathrm{~cm}$ for dbh on bark $(42 \mathrm{~cm} ; 104 \mathrm{~cm}), 153$ for ring number at bh $(61 ; 224)$ and $1.9 \mathrm{~mm}$ for average ring width at bh $(1.3 \mathrm{~mm} ; 3.9 \mathrm{~mm})$. Means of these characteristics at region, silvicultural schedule and site quality levels are given in Table 2.

Table 1 Number of trees and plots sampled in each of the $2 \times 5 \times 3$ combinations silvicultural schedule $\times$ region $\times$ site quality

\begin{tabular}{|c|c|c|c|c|c|c|}
\hline \multirow[t]{2}{*}{ Silvicultural schedule } & \multirow[t]{2}{*}{ Region } & \multirow[t]{2}{*}{$\begin{array}{l}\text { Site } \\
\text { quality }\end{array}$} & \multirow[t]{2}{*}{$\begin{array}{l}\text { Number } \\
\text { of trees }\end{array}$} & \multicolumn{3}{|c|}{$\begin{array}{l}\text { Number of plots in each } \\
\text { combination }\end{array}$} \\
\hline & & & & Total & $\begin{array}{l}\text { 1-tree } \\
\text { plot }\end{array}$ & $\begin{array}{l}\text { 2-tree } \\
\text { plot }\end{array}$ \\
\hline \multirow[t]{15}{*}{ High forest } & \multirow[t]{3}{*}{ Alsace } & High & 8 & 4 & 0 & 4 \\
\hline & & Medium & 6 & 3 & 0 & 3 \\
\hline & & Poor & 2 & 1 & 0 & 1 \\
\hline & \multirow[t]{3}{*}{ Allier } & High & 4 & 2 & 0 & 2 \\
\hline & & Medium & 2 & 1 & 0 & 1 \\
\hline & & Poor & 4 & 2 & 0 & 2 \\
\hline & \multirow[t]{3}{*}{ Lorraine } & High & 3 & 2 & 1 & 1 \\
\hline & & Medium & 4 & 2 & 0 & 2 \\
\hline & & Poor & 2 & 2 & 2 & 0 \\
\hline & \multirow[t]{3}{*}{ Orne-Sarthe } & High & 4 & 2 & 0 & 2 \\
\hline & & Medium & 0 & 0 & 0 & 0 \\
\hline & & Poor & 4 & 2 & 0 & 2 \\
\hline & \multirow[t]{3}{*}{ Loir-et-Cher } & High & 2 & 1 & 0 & 1 \\
\hline & & Medium & 2 & 1 & 0 & 1 \\
\hline & & Poor & 0 & 0 & 0 & 0 \\
\hline \multirow[t]{15}{*}{ Coppice with standard } & \multirow[t]{3}{*}{ Alsace } & High & 0 & 0 & 0 & 0 \\
\hline & & Medium & 2 & 1 & 0 & 1 \\
\hline & & Poor & 0 & 0 & 0 & 0 \\
\hline & \multirow[t]{3}{*}{ Allier } & High & 2 & 1 & 0 & 1 \\
\hline & & Medium & 3 & 2 & 1 & 1 \\
\hline & & Poor & 3 & 3 & 3 & 0 \\
\hline & \multirow[t]{3}{*}{ Lorraine } & High & 3 & 2 & 1 & 1 \\
\hline & & Medium & 2 & 2 & 2 & 0 \\
\hline & & Poor & 4 & 3 & 2 & 1 \\
\hline & \multirow[t]{3}{*}{ Orne-Sarthe } & High & 2 & 1 & 0 & 1 \\
\hline & & Medium & 4 & 2 & 0 & 2 \\
\hline & & Poor & 2 & 1 & 0 & 1 \\
\hline & \multirow[t]{3}{*}{ Loir-et-Cher } & High & 2 & 1 & 0 & 1 \\
\hline & & Medium & 5 & 3 & 1 & 2 \\
\hline & & Poor & 1 & 1 & 1 & 0 \\
\hline Total & & & 82 & 48 & 14 & 34 \\
\hline
\end{tabular}


Table 2 Number of trees and mean of the tree characteristics according to the five regions, the two silvicultural schedules and the three site qualities sampled (total tree number $=82$ )

\begin{tabular}{lcccccc}
\hline & $\begin{array}{l}\text { Number } \\
\text { of trees }\end{array}$ & $\begin{array}{l}\text { Total } \\
\text { height } \\
(\mathrm{m})\end{array}$ & $\begin{array}{l}\text { Height } \\
\text { of the } \\
\text { crown } \\
\text { base (m) }\end{array}$ & $\begin{array}{l}\text { Dbh on } \\
\text { bark (cm) }\end{array}$ & $\begin{array}{l}\text { Ring } \\
\text { number } \\
\text { at bh }\end{array}$ & $\begin{array}{l}\text { Average } \\
\text { ring width } \\
\text { at bh (mm) }\end{array}$ \\
\hline Region & 18 & 33.7 & 19.3 & 61.1 & 162 & 1.76 \\
$\quad$ Alsace & 18 & 27.2 & 11.5 & 57.4 & 137 & 2.05 \\
$\quad \begin{array}{l}\text { Allier } \\
\text { Lorraine }\end{array}$ & 18 & 26.9 & 12.3 & 66.5 & 168 & 1.84 \\
$\quad \begin{array}{l}\text { Orne-Sarthe } \\
\text { Loir-et-Cher }\end{array}$ & 16 & 25.1 & 11.6 & 59.5 & 146 & 1.90 \\
Silvicultural schedule & 12 & 27.6 & 12.5 & 69.1 & 151 & 2.11 \\
$\quad$ High forest & 47 & 31.8 & 17.3 & 57.4 & 162 & 1.64 \\
$\quad \begin{array}{l}\text { Coppice with standard } \\
\text { Site quality }\end{array}$ & 35 & 23.4 & 8.5 & 68.9 & 141 & 2.31 \\
$\quad$ High site quality & 30 & 31.8 & 16.2 & 65.3 & 160 & 1.94 \\
$\quad \begin{array}{l}\text { Medium site quality } \\
\text { Low site quality }\end{array}$ & 30 & 27.5 & 12.8 & 64.8 & 147 & 2.09 \\
\hline
\end{tabular}

Decay resistance measurements

Weight loss due to fungus $C$. versicolor was measured in a laboratory test according to the norms NF EN 350-1 (AFNOR 1994a) and NF EN 113 (AFNOR 1986). The total number of samples was 614 (LRT dimensions $50 \mathrm{~mm} \times 20 \mathrm{~mm} \times 15 \mathrm{~mm}$ ) while 83 additional samples (same dimensions) of beech (Fagus sylvatica L.) were used as a control. Samples were sawn at breast height on two opposite radii and each radius was represented by four heartwood samples regularly placed from pith to the limit between heartwood and sapwood (the theoretical number of $656=82 \times 2 \times 4$ samples was not reached due to the small size of some trees).

Weight loss (in \%) of each of the 614 samples was defined as follows:

Weight loss $=100 \times\left(P_{0 \mathrm{i}}-P_{0 \mathrm{f}}\right) / P_{0 \mathrm{i}}$

where $P_{0 \mathrm{i}}$ and $P_{0 \mathrm{f}}$ are the oven-dry weights of the sample before and after exposition to $C$. versicolor.

All the statistical analyses that follow have been conducted on the abovedefined weight loss except when evaluating the percentage of samples and trees in each of the five classes of natural durability defined by the norm NF EN 3502 (AFNOR 1994b).

\section{Ellagitanin content measurements}

Total content of ellagitanins and content of each of them (roburine A, B, C, D and E, grandinin, vescalagin and castalagin) were obtained by HPLC analysis after sample extraction with organic solvent (aceton 80\%). The two samples used for each tree were very close to the ones used for weight loss measurements and situated close to the sapwood. Each sample was extracted in minimum twice and each ellagitanin was exprimed in equivalent of pyrogallol used as internal standard and total content of ellagitanins correspond to the sum of the eight ellagitanins taken into consideration. 
Other data available

In addition to the tree growth descriptors mentioned in Table 2, the following data were collected in the course of the present study or provided by researchers who previously worked on the same 82 trees. These data are as follows:

- Average ring width, ring number from the pith, ring number from the sapwood as well as air-dry density of each of the 614 samples submitted to C. versicolor

- Optic density of total wood extract at $280 \mathrm{~mm}$ (which is well correlated with tanin content), concentration of trans- and cis-méthyl-octalactone and eugenol for each tree based on two measurements near the sapwood (methodology explained in Snakkers et al. (2000))

- Intrinsic tree value for grain angle as described in Guilley et al. (1999)

- Mean tree value for three multiseriate wood rays descriptors (lineic percentage, number per $\mathrm{cm}$ and average width) as explained in Dendane (1996)

- Mean tree value for tangential and radial swelling coefficients as explained in Le Moguédec et al. (2002)

\section{Modelling strategy}

A model (1) of analysis of variance first tested three effects: "tree", "radial position" and the interaction of those effects on weight loss. A mixed model (2) for weight loss was then tested. Parameters measured at the tree level were accounted as random effects:

Weight $\operatorname{Loss}_{\mathrm{ij}}=\mathrm{a}+\alpha_{\mathrm{i}}+\varepsilon_{\mathrm{ij}}$

The index $\mathrm{i}$ denotes the $\mathrm{i}^{\text {th }}$ tree and $\mathrm{j}$ the $\mathrm{j}^{\text {th }}$ radial position. The term a corresponds to the overall population mean. The random "tree" effect, $\alpha_{\mathrm{i}}$, and the residual errors, $\epsilon_{\mathrm{ij}}$, were assumed to follow a normal distribution. A mixed model (3) for weight loss was tested with silviculture, region, site quality and interactions of those effects as fixed explanatory variables.

Weight $\operatorname{Loss}_{(\mathrm{rst}) \mathrm{ij}}=\left(\mathrm{a}+(\Delta \mathrm{a})_{\mathrm{rst}}\right)+\alpha_{(\mathrm{rst}) \mathrm{i}}+\varepsilon_{(\mathrm{rst}) \mathrm{ij}}$

The index $r$ denoted the $r^{\text {th }}$ region; $s$ the $s^{\text {th }}$ site quality; $t$ the $t^{\text {th }}$ silviculture. The term a corresponds to the overall population mean and (a) $)_{\text {rst }}$ to the fixed deviations due to the "region", "site quality", and "silviculture" effects as well as their interactions from mean.

A maximum of four repeated stands, each with one or two trees, were taken at random within a given combination of region, site quality, and silviculture. The random "tree" variation quantified in models (2) or (3) may consequently be provoked either by between-stand variability and/or by between-tree within stand variability. In order to quantify the relative importance of both variabilities, the "stand" effect was introduced into the following model (4):

Weight $\operatorname{Loss}_{(\mathrm{p}) \mathrm{ij}}=\mathrm{a}+\alpha_{\mathrm{p}}^{\prime}+\alpha_{(\mathrm{p}) \mathrm{i}}+\varepsilon_{(\mathrm{p}) \mathrm{ij}}$

where $\mathrm{p}$ denotes the $\mathrm{p}^{\text {th }}$ stand. $\operatorname{Var}\left(\alpha_{\mathrm{p}}\right)$ and $\operatorname{Var}\left(\alpha_{(\mathrm{p}) \mathrm{i}}\right)$ are the variances due to the "stand" effect and to the "tree in stand" effect, respectively. The 14 
stands with a single tree were not taken into account to avoid unbalanced number of trees per stand. Only the 34 stands, each with a pair of trees for a total of 68 trees, were analysed. Model (1) was fitted using the General Linear Models Procedure of SAS/STAT; fixed and random effects of models (2), (3) and (4) were tested by the method of restricted maximum likelihood using the procedure PROC MIXED available in version 6.11 of SAS/STAT (Littell et al. 1996).

Table 3 Analysis of variance on the "tree", "radial position" and interaction "treexradial position" effects on percent weight loss

\begin{tabular}{|c|c|c|c|c|c|}
\hline $\begin{array}{l}\text { Sources of } \\
\text { variation }\end{array}$ & df & $\begin{array}{l}\text { Mean } \\
\text { square }\end{array}$ & Type III expected mean square & $F$ value & $\operatorname{Pr}>F$ \\
\hline Tree & 81 & 650.34 & $\begin{array}{l}\operatorname{Var}(\text { error })+1.8705 \operatorname{Var}(\text { tree } \times \text { radial } \\
\text { position) }+7.313 \operatorname{Var} \text { (tree) }\end{array}$ & ${ }_{239.15}^{81} F=9.56$ & 0.0001 \\
\hline Radial position & 3 & 2316.59 & $\begin{array}{l}\text { Var(error) + 1.8513Var(treexradial } \\
\text { position) }+147.02 \operatorname{Var}(\text { radial } \\
\text { position) }\end{array}$ & ${ }_{241.36}^{3} F=34.25$ & 0.0001 \\
\hline $\begin{array}{l}\text { Tree } \times \text { radial } \\
\text { position }\end{array}$ & 235 & 68.76 & $\begin{array}{l}\text { Var(error) }+1.9076 \operatorname{Var}(\text { tree } \times \text { radial } \\
\text { position) }\end{array}$ & ${ }_{239}^{235} F=2.25$ & 0.0001 \\
\hline Error & 294 & 30.58 & & & \\
\hline Total & 613 & & & & \\
\hline
\end{tabular}

Table 4 Decomposition of the total variation for weight loss

\begin{tabular}{ll}
\hline Sources of variation & Contribution to the total variation \\
\hline Tree & $54.7 \%$ \\
Radial position & $10.5 \%$ \\
Tree $\times$ radial position & $13.7 \%$ \\
Error & $21.0 \%$ \\
Total & $100 \%$ \\
\hline
\end{tabular}

Table 5 Mean weight loss and ellagitanin content for each of the four radial positions from pith to sapwood limit sampled in the heartwood

\begin{tabular}{lccc}
\hline Radial position & $\begin{array}{c}\text { Mean weight } \\
\text { loss }\end{array}$ & $\begin{array}{c}\text { Number of } \\
\text { samples }\end{array}$ & $\begin{array}{c}\text { Ellagitanin } \\
\text { content*(mg eq. } \\
\text { Pyrogallol.g }\end{array}$ \\
\hline Position 1 (close to the pith) & $15.60 \%$ & 156 & $68,6\left(13,0^{* *}\right)$ \\
Position 2 (inner heartwood) & $12.94 \%$ & 139 & $128,5(15,2)$ \\
Position 3 (outer heartwood) & $9.86 \%$ & 158 & $220,0(29,6)$ \\
Position 4 (close to the sapwood) & $6.40 \%$ & 161 & $414,3(65,9)$ \\
\hline
\end{tabular}

*mean of 10 samples per radial position from 10 different trees and extracted three times ** standard error

Fig. 1 a) Mean weight loss (based on an average of seven measurement per tree) and b) optic density at $280 \mathrm{~nm}$ (two measurements per tree) for each of the 82 sessile oak trees sampled. The 18 trees sampled in the Alsace region are underlined with a white bar (refer further to Tables 8 and 9) 

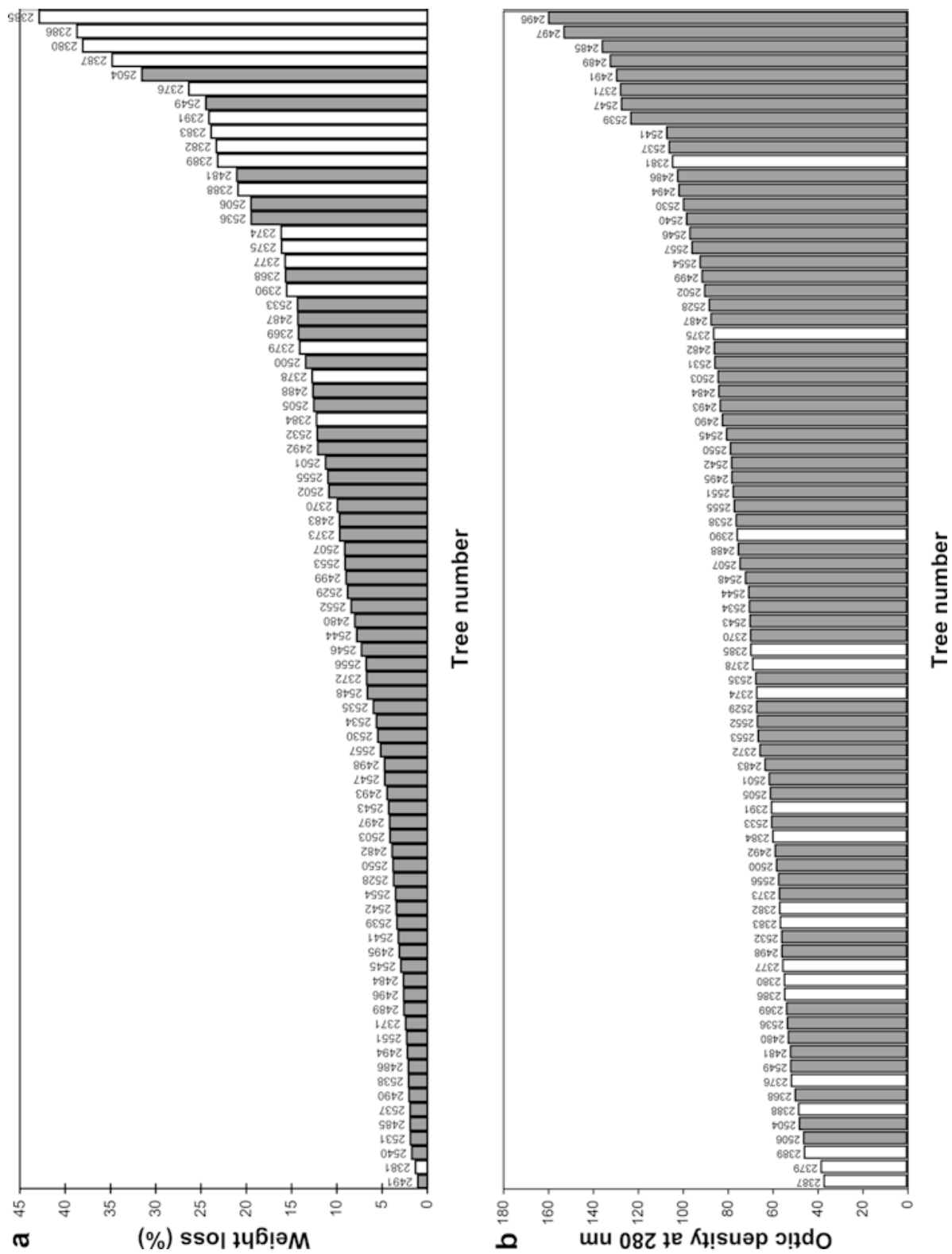


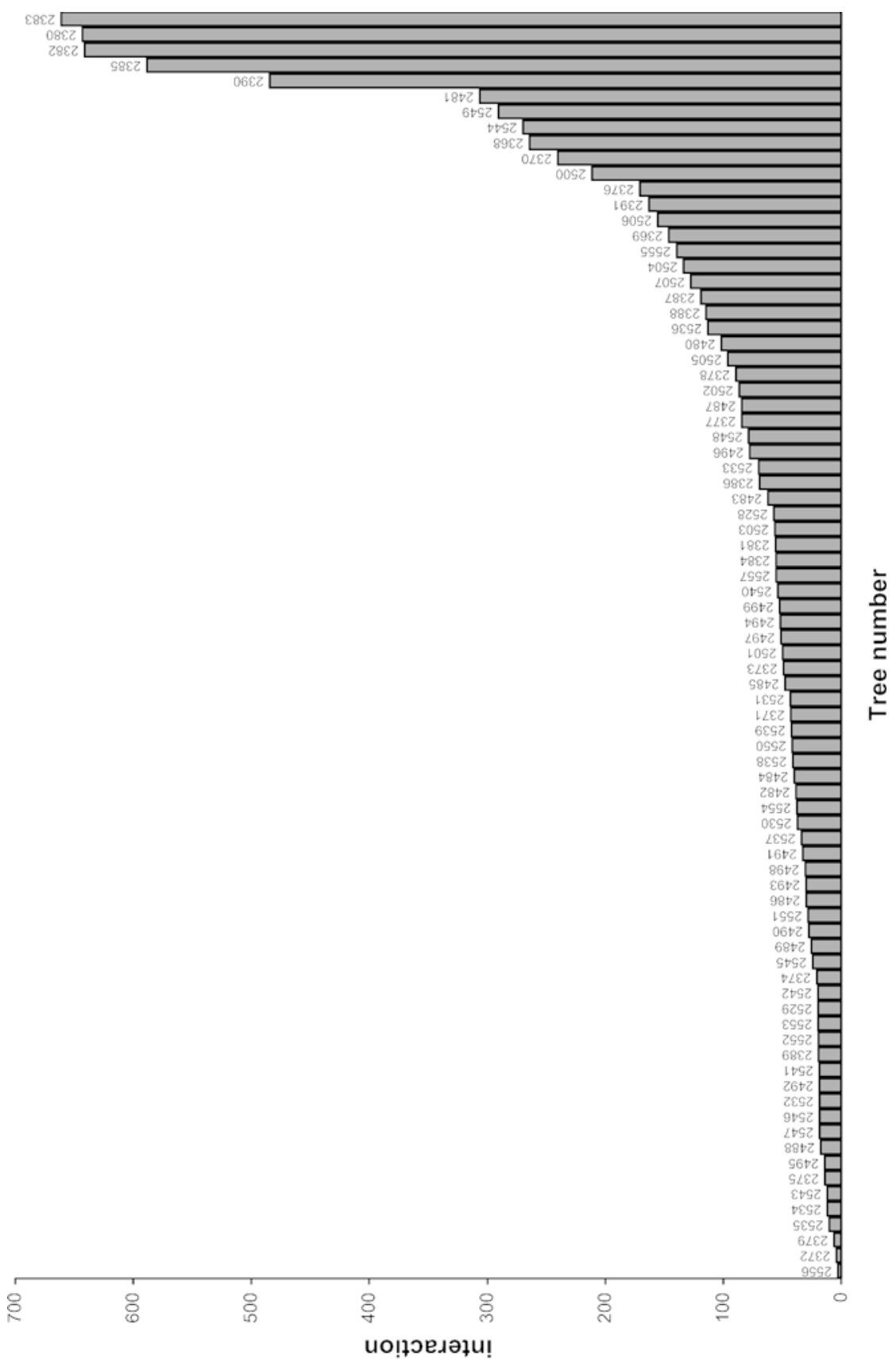

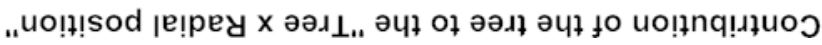




\section{Results and discussion}

Between- and within-tree variability for weight loss

Table 3 presents the results of a variance analysis with "tree" and "treexradial position" as random effects. Table 4 gives the decomposition of the total variation for weight loss, and Table 5 shows the mean weight loss and ellagitanin content for each of the four radial positions from pith to sapwood limit sampled in the heartwood.

Figure $1 \mathrm{a}$ and $1 \mathrm{~b}$ illustrate the between-tree variability for weight loss and optic density observed between the 82 sessile oak trees sampled. Figure 2 shows the contribution of each of the 82 trees sampled to the "treexradial position" sum of squares of the analysis of variance presented in Table 3.

The following comments can be made from the above presented tables and figures:

- The high part of the total variation for weight loss is explained when taking into account tree, radial position and interaction between them $(54.7+10.5+13.7=79.0 \%$; Table 4$)$.

- The relatively low level of the residual variation (contribution to the total variation is $21.0 \%$; Table 4) means that the variability between opposite radii in a tree for the same radial position is low.

- From the three controlled sources of variation, between-tree variability is the most important if compared to the "radial position" effect (Table 4; Fig. 1; Table 5). Extremes of tree means for weight loss observed are between $1 \%$ (tree 2491) and $43 \%$ (tree 2385) as compared to the extremes for radial position with means of $6.40 \%$ close to the sapwood to $15.60 \%$ close to the pith.

- The significant interaction between tree and radial position (Table 3; Table 4) shows that the general pattern for variation in the heartwood from pith to sapwood limit (Table 5) is not followed by all the trees. Atypical trees appear, however scarce, as shown in Fig. 2 (few trees contribute noticeably to the treexradial position interaction).

With regard to the significance of the tree effect our results are in agreement with the bibliography works from Viitanen et al. (1998) on L. sibirica, Srinivasan et al. (1999) on L. laricina, Dumonceaud (2001) on C. sativa, and Freitag and Morrell (2001) on T. plicata. For oak however, it is the first time (with Ayadi et al. 2001) that, in addition to testing the "tree effect", such a high level of between-tree variability is proved for decay resistance.

With regard to the radial variation our results are to some extent in agreement with De Groot (2000) on Chamaecyparis nootkatensis and Dumonceaud (2001) on C. sativa, both of them pointing however to an interaction between fungus species and radial position while the second one identifies (as ourselves) an interaction between treexradial position for weight loss. In contrast, Freitag and Morrell (2001) did not identify significant radial variation for natural durability in T. plicata.

Fig. 2 Contribution of each of the 82 sessile oak trees sampled to the "treexradial position" sum of squares from the analysis of variance presented in Table 3 
Number of trees and individual samples in natural

durability classes defined by the norm NF EN 350-2

As the five durability classes proposed by the norm NF EN 350-2 (AFNOR 1994b) are defined relative to a poorly durable control (in our case beech wood represented by a total of 83 samples), we have defined for each of the 614 samples the following criterion:

$x=\left(P_{0 \mathrm{i}}-P_{0 \mathrm{f}}\right) / \operatorname{Mean}\left(P_{0 \mathrm{i}}-P_{0 \mathrm{f}}\right)$

where $P_{0 \mathrm{i}}$ and $P_{0 \mathrm{f}}$ are the oven-dry weight of the oak sample before and after exposition to $C$. versicolor and mean $\left(P_{0 \mathrm{i}}-P_{0 \mathrm{f}}\right)$ is the mean of the oven-dry weight loss for the 83 beech samples taken as control.

The norm NF EN 350-2 (AFNOR 1994b) defines the class of durability in relation to $x$ as follows:
$x \leq 0.15$
class 1 (very durable)
$0.15<x \leq 0.30$
class 2 (durable)
$0.30<x \leq 0.60$
class 3 (moderately durable)
$0.60<x \leq 0.90$
class 4 (poorly durable)
$x>0.90$
class 5 (no durable)

Table 6 presents the repartition of the 614 individual wood pieces as well as the 82 tree means in the five classes of natural durability. Table 6 proves that grading of Sessile oak wood by NF EN 350-2 in class 2 of natural durability is somewhat too severe as $62.7 \%$ of the samples and $54.9 \%$ of the trees are classified as "very durable" (class 1). Related to the tree effect, it appears important to underline that 27 of 45 trees classified (on average) as "very durable" have all their individual samples classified as "very durable".

Origin of the between-tree variability for weight loss

In this section we will try to elucidate the origin of the high level of variability observed at tree level. Assuming that, we will consider the 7.48 samples available in each tree $(614 / 82)$ as replications in order to simulate the situation most often encountered in the wood industry (no possibility to sort the pieces according to their radial position in the tree).

Table 6 Repartition (in percentage) of the 614 individual wood pieces and the 82 trees in the five classes of natural durability defined by the norm NF EN 350-2 (AFNOR 1994b)

\begin{tabular}{lcccccc}
\hline & $n$ & $\begin{array}{l}\text { Class 1 } \\
\text { (very } \\
\text { durable) }\end{array}$ & $\begin{array}{l}\text { Class 2 } \\
\text { (durable) }\end{array}$ & $\begin{array}{l}\text { Class 3 } \\
\text { (moderately } \\
\text { durable) }\end{array}$ & $\begin{array}{l}\text { Class 4 } \\
\text { (poorly } \\
\text { durable) }\end{array}$ & $\begin{array}{l}\text { Class 5 } \\
\text { (not } \\
\text { durable) }\end{array}$ \\
\hline $\begin{array}{l}\text { Individual wood samples } \\
\text { Individual wood samples }\end{array}$ & 614 & 62.7 & 16.6 & 16.6 & 3.6 & 0.5 \\
$\begin{array}{l}\text { in each radial position: } \\
\text { - close to the pith }\end{array}$ & 156 & 44.2 & 19.9 & 26.9 & 7.7 & 1.3 \\
$\quad$ - inner heartwood & 139 & 54.7 & 19.4 & 21.6 & 4.3 & 0.0 \\
$\quad$ - outer heartwood & 158 & 65.8 & 17.7 & 14.6 & 1.3 & 0.6 \\
- close to the sapwood & 161 & 84.5 & 9.9 & 4.3 & 1.2 & 0.0 \\
Tree mean & 82 & $54.9^{*}$ & 29.3 & 14.6 & 1.2 & 0.0 \\
\hline
\end{tabular}

* In which 27 trees on 45 have all their samples classified as "very durable" 
Table 7 Estimations of the between-tree variance for weight loss in three situations: 82-tree population, tree in combination silvicultural schedulexregion $\times$ site quality, tree in stand (for details see the text)

Tree sampling

82 trees

82 trees

68 of the 82 trees
Between-tree variance estimate

82-tree population (one-way analysis of variance); $\operatorname{Model}(2)$

Tree in combination silvicultural schedule $\times$ region $\times$ site quality (nested analysis of variance); Model(3)

Tree in stand (nested analysis of variance); $\operatorname{Model}(4)$
81.84

44.38

52.71

Referring to Table 1 it can be seen that the 82 trees have been sampled so that they represent combinations of silvicultural schedules ( 2 modalities), regions (5 modalities) and site qualities (3 modalities). Each of these (theoretical) $30 \mathrm{com}$ binations is represented by 0 (4 cases/30), $1(10 / 30), 2(11 / 30), 3(4 / 30)$ or $4(1 / 30)$ plots, each of which corresponding to a forest stand. Fourteen of these plots are a one-tree plot (14 trees sampled) and 34 plots are two-tree plots (68 trees sampled). Table 7 gives estimations of the between-tree variance for weight loss in three situations, each corresponding to one analysis of variance (Littell et al. 1996):

- In model(2) we did not consider that trees are split according to plots; we considered having a single 82 -tree population. We have performed a oneway analysis of variance: tree, sample in tree.

- In model(3) we have taken into consideration the 26 combinations represented by one or more trees and we have performed a nested analysis of variance: combination, tree in combination, sample in tree.

- In model(4) we considered the 34 two-tree plots and again performed a nested analysis of variance: stand, tree in stand, sample in tree.

A decrease in the between-tree variance estimate seen in Table 7 when going from the single 82 -tree population (variance $=81.84$ ) to the tree effect nested in combination silvicultural schedule $\times$ region $\times$ site quality $($ variance $=44.38$ ) shows that, even if a large part of the between-tree variance is found at an intra-stand level (which suggests a strong genetic control on decay resistance as demonstrated by Viitanen (1998) in L. sibirica), a significant part of the between-tree variability $(81.84-44.38 / 81.84=46 \%)$ is under control of the effects taken into account through our experimental design (see below). Surprisingly, a (slight) increase of the between-tree variance (from 44.38 to 52.71 ) is observed when passing from within-combination silvicultural schedule $\times$ region $\times$ site quality level (in each of which several stands can be represented; see Table 1) to withinstand level. This somewhat surprising result could be related to the slight change in tree sampling between the two situations (from 82 to 68 trees).

In Table 8 , the effect of the silvicultural schedule, region and site class and their interactions are tested relative to the tree effect in each combination. Table 8 also shows that, in addition to the tree effect in combination silvicultural schedule $\times$ region $\times$ site class already proved as highly significant, only the "region" effect is statistically significant $(\mathrm{F}=9.73$; $\operatorname{Pr}<0.0001)$.

Table 9 shows that, with a poor decay resistance, the Alsace region clearly discriminates from the four other regions sampled (weight loss is $22.19 \%$ 
Table 8 Analysis of variance on the effects of the silvicultural schedule, region and site class, their interaction and tree effect in their combination

\begin{tabular}{lll}
\hline Effect tested & $\begin{array}{l}F \text { test (fixed effects) } \\
\text { and } Z \text { test } \\
\text { (random effects) }\end{array}$ & Pr \\
\hline Silvicultural schedule & ${ }_{56} F=0.88$ & 0.3517 \\
Region & $4{ }_{56} F=9.73$ & 0.0001 \\
Site class & $2{ }_{56} F=2.42$ & 0.0984 \\
Silvicultural schedule $\times$ region & $4{ }_{56} F=1.44$ & 0.2322 \\
Silvicultural schedule $\times$ site class & $2{ }_{56} F=1.07$ & 0.3508 \\
Region $\times$ site class & $856=0.25$ & 0.9789 \\
Silvicultural schedule $\times$ region $\times$ site class & ${ }_{56} F=1.04$ & 0.3929 \\
Tree in silvicultural schedule $\times$ region $\times$ site class & $Z=4.48$ & 0.0001 \\
Sample in tree $($ residual) & $Z=16.32$ & 0.0001 \\
\hline
\end{tabular}

Analysis of variance performed using the mixed procedure of SAS (Littell et al. 1996)

Table 9 Weight loss mean in each region; 7.48 samples in each tree

\begin{tabular}{lcc}
\hline Region & Number of trees & Weight loss \\
\hline Allier & 18 & $6.03 \%$ \\
Alsace & 18 & $22.19 \%$ \\
Loir et Cher & 12 & $6.94 \%$ \\
Lorraine & 18 & $8.81 \%$ \\
Orne-Sarthe & 16 & $9.41 \%$ \\
\hline
\end{tabular}

compared to between $6.03 \%$ and $9.41 \%$ for the four other regions; see above Fig. 1 in which the 18 trees sampled in Alsace are underlined). An attempt to explain the singularity of the Alsace region follows.

Correlations at tree level between weight loss

and growth and basic wood properties data

Correlations $R$ at tree level ( $n=82$ ) between weight loss and several descriptors of the tree growth and basic wood properties are given in Table 10 from which several conclusions appear:

- The relatively poor level of the highest correlation seen $\left(\mathrm{R}=+0.637^{* * *}\right.$ with height of the crown base) shows that, at this stage, no hope exists to use one simple descriptor of tree growth or basic wood properties to identify with confidence individual trees exhibiting a high (or poor) level of decay resistance to $C$. versicolor.

- The tallest trees $\left(\mathrm{R}=+0.540^{* * *}\right)$ as well as trees having the longest log under crown base $\left(\mathrm{R}=+0.637^{* * *}\right)$ appear to exhibit lower decay resistance. This finding however does not mean that silvicultural schedules having good external qualities (i.e. high log length under crown) also give poor decay resistance since we have seen (Table 8) that silvicultural schedule does not have any effect on decay resistance. Referring to the singularity of the Alsace region for weight loss (Fig. 1, Table 9) as well as for total height and height of the crown base (Table 2), we consider that those correlations of 
Table 10 Correlations $\mathrm{R}$ at tree level $(\mathrm{n}=82)$ between weight loss and several descriptors of the tree growth and basic wood properties. All the basic wood properties taken into consideration here have been proved to be under a strong tree control (Dendane 1996; Guilley et al. 1999; Guilley et al. 2004; Le Moguédec et al. 2002; Snakkers et al. 2000; as well as analysis of variance of the tree effect done in the frame of the present study for ellagitanins but not presented here)

Descriptor of the tree growth and basic wood properties

Correlation $R$

Tree descriptors

- Total height

- Height of the crown base

- Dbh on bark

- Ring number at bh

- Average ring width at bh

Descriptors of the samples submitted to Coriolus versicolor

(7.48 samples in each tree)

- Average ring width

- Ring number from the pith

- Ring number from the sapwood

- Air-dry density

Extractives

- Optic density at $280 \mathrm{~nm}$

- Trans-methyl-octalactone

- Cis-methyl-octalactone

- Eugenol

$-\sum$ of ellagitanins

- Roburine A

- Roburine B

- Roburine C

- Roburine D

- Roburine E

- Grandinin

- Vescalagin

- Castalagin

Grain angle

Multiseriate wood rays descriptors

- lineic percentage

- number/cm in tangential direction

- mean width

Swelling coefficients

- tangential

- radial

\begin{tabular}{|c|c|}
\hline+ & 0.540 \\
\hline+ & 0.637 \\
\hline- & 0.166 \\
\hline+ & 0.198 \\
\hline - & 0.300 \\
\hline- & 0.291 \\
\hline+ & 0.203 \\
\hline+ & 0.228 \\
\hline- & 0.363 \\
\hline - & 0.616 \\
\hline+ & 0.118 \\
\hline+ & 0.059 \\
\hline - & 0.235 \\
\hline- & 0.544 \\
\hline- & 0.339 \\
\hline- & 0.446 \\
\hline - & 0.503 \\
\hline - & 0.625 \\
\hline - & 0.534 \\
\hline - & 0.534 \\
\hline - & 0.351 \\
\hline - & 0.520 \\
\hline - & 0.264 \\
\hline - & 0.292 \\
\hline+ & 0.005 \\
\hline - & 0.405 \\
\hline+ & 0.449 \\
\hline+ & 0.385 \\
\hline
\end{tabular}

$* * *, * *, *$, NS: correlation respectively significant at $1 \%, 1 \%, 5 \%$ and not significant. Tree mean for weight loss based on 7.48 measurements in each.

weight loss with total tree height and height of the crown base are artefacts due to the singularity of the Alsace region both for weight loss and total height/height of the crown base.

- No clear (and/or direct) significant relationships appear between weight loss and traits describing either radial growth of the trees (only $\mathrm{R}=-0.300^{* *}$ with average ring width at bh) nor average ring width (at tree level) of the samples used for weight loss measurements $\left(\mathrm{R}=-0.291^{* *}\right)$.

- Descriptors related to tree age (ring number at bh of the tree, average ring number from the pith or from the sapwood of the samples used for weight loss measurements) do not appear to play any role on weight loss at tree level. 
- Phenotypic tree selection for high decay resistance (i.e. poor weight loss) would statistically result in increasing wood density $\left(\mathrm{R}=-0.363^{* * *}\right)$, decreasing swelling coefficients $\left(\mathrm{R}=0.449^{* * *}\right.$ for tangential swelling and $\mathrm{R}=0.385^{* * *}$ for radial swelling) and increasing percentage and width of multiseriate wood rays $\left(\mathrm{R}=-0.292^{* *}\right.$ and $-0.405^{* * *}$, respectively).

- Practically no adverse correlation is seen between grain angle and weight loss $(\mathrm{R}=-0.264 *)$.

- No correlation appears at tree level between weight loss and octalactone contents but clear relationships are detected between total content in ellagitanins estimated through optic density at $280 \mathrm{~nm}\left(\mathrm{R}=-0.616^{* * *}\right)$ and directly measured $(\mathrm{R}=-0.544 * * *)$,

- trees having higher ellagitanin content (near the sapwood) clearly exhibit statistically higher natural durability. When considering the correlations of weight loss with each of the eight constitutive tanins taken into consideration (roburin $\mathrm{A}, \mathrm{B}, \mathrm{C}, \mathrm{D}$, and $\mathrm{E}$, grandinin, vescalagin, castalagin), we note that practically none of them appears to explain more weight loss than the other ones. These findings related to the relationships between decay resistance and extractives content are in good agreement with the information given in the literature by Viitanen (1997) in Larix spp. and Dumonceaud (2001) in C. sativa but not confirmed by Srinivasan et al. (1999) in L. laricina. If a method would be available to realistically sort trees in the forest or logs in the sawmill for their extractive contents, the level of the univariate correlations observed here appears too low to ensure more than a statistical improvement for natural durability. However, these relationships should appeal to further research. For instance, a multivariate model between extractives proportions and decay resistance could be adjusted. This model must take into account the high correlations between extractives proportions and it goes beyond the concerns of this preliminary study.

Globally our findings can be compared with that of a large sampling by Freitag and Morrell (2001) on T. plicata who concluded that "weight losses varied widely among and between sites and were not correlated with position in the heartwood across section, tree age or silvicultural factors".

\section{Summary and conclusions}

Based on a large intra- and inter-tree sampling this research evidenced several original results related to decay resistance against $C$. versicolor in Sessile oak:

- The control of the tree is very strong on decay resistance $(54.7 \%$ of the total variation); this is associated with a very large between-tree variability (from $1-43 \%$ in weight loss for extreme trees).

- Related to the between-tree variability, the radial variation appears relatively low (10.5\% of the total variation) and most of the trees exhibit the same patterns, i.e. regular decrease in decay resistance from outer to inner heartwood.

- A large part of the individual wood pieces and trees reach class 1 ("very durable") for natural durability defined by the norm NF EN 350-2. It 
means that if efficient methods could be found to sort individual trees and/ or logs for decay resistance, large amount of Sessile oak lumber (from our results, more than $60 \%$ of the French resource) could be used outdoor without chemicals to protect it. To this point we remember that, according to the norm NF EN 350-2, oak wood is classified only as "durable" (class 2).

- Even if the huge between-tree variability for decay resistance is high at the intra-stand level, a significant part of the between-tree variability appeared under regional control, the other effect (silvicultural schedule and fertility class) being insignificant. Of the five regions sampled in France, the Alsace region exhibits low decay resistance compared to the other four.

- Significant correlations appeared at tree mean level between ellagitanin content and decay resistance. Those relationships should appeal to further research. No adverse correlations were detected between other basic wood properties and decay resistance.

The univariate correlations between ellagitanin content and decay resistance are encouraging. A more intensive exploitation of the large database gained in the frame of the study and multivariate analyses could result in efficient and realistic means to identify trees and logs of high natural durability and, as a result, to enlarge the use of this important resource in France.

Acknowledgements This study was supported by ADEME and DERF (France) in the frame of a project from "Programme Concerté Bois Matériau" entitled Durachêne coordinated by Dr. Bertrand Charrier of the Ecole Supérieure du Bois in Nantes. The study was carried out with the technical collaboration of André Perrin, Claude Houssement and Marc Doidy (LERFOB)for samples preparation and Nathalie Boizot (Unité Amélioration, Génétique et Physiologie Forestières) for biochemical analyses.

\section{References}

AFNOR (1986) Norme NF EN 113: Produits de préservation des bois. Détermination du seuil d'efficacité contre les champignons basidiomycètes lignivores cultivés sur milieu gélosé.

AFNOR (1994a) Norme NF EN 350-1: Durabilité du bois et des matériaux dérivés du bois. Durabilité naturelle du bois massif. Partie 1: Guide des principes d'essai et de classification de la durabilité naturelle du bois

AFNOR (1994b) Norme NF EN 350-2: Durabilité du bois et des matériaux dérivés de bois. Durabilité naturelle du bois massif. Partie 2: Guide de la durabilité naturelle du bois et de l'imprégnabilité d'essences de bois choisies pour leur importance en Europe.

Ayadi N, Charrier B, Irmouli M, Charpentier JP, Jay-Allemand C, Feuillat F, Keller R (2001) Interspecific variability of european oak durability against white rot fungi (Coriolus versicolor): Comparison between sessile oak and pedunculate oak (Quercus petraea and Quercus robur). In: International Research Group on Wood Preservation. International Research Group on Wood Preservation, Nara, Japan

De Groot R, Woodward B, Hennon PE (2000) Natural decay resistance of heartwood from dead, standing yellow-cedar trees: laboratory evaluations. Forest Prod J 50(1):53-59

Dendane A (1996) Analyse de la variabilité de quelques caractéristiques des gros rayons ligneux chez le Chêne rouvre (Quercus petraea Liebl.). Possibilité d'une estimation non destructive en forêt. Rapport de stage. Document Equipe de Recherches sur la Qualité des Bois, 1996/3, p 74

Dumonceaud O (2001) Petits bois naturellement durables dans des usages extérieurs en vue de limiter l'emploi des traitements par les pesticides: problèmes posés par l'utilisation du Châtaignier (Castanea sativa Mill.) et intérêts d'un traitement de type friture à basse température. Thèse de Docteur de l'Engref, p 214

Freitag CM, Morrell JJ (2001) Durability of a changing western redcedar resource. Wood Fiber Sci 33(1):69-75 
Guilley E, Loubère M, Nepveu G (1999) Identification en forêt de chênes sessiles (Quercus petraea) présentant un angle du fil du bois intrinsèquement faible. Can $\mathrm{J}$ For Res 29(12):1958-1965

Guilley E, Hervé JC, Nepveu G (2004) The influence of site quality, silviculture and region on the wood density-radial growth relationship in Quercus petraea Liebl. For Ecol Manage 189(1-3):111-121

Le Moguédec G, Dhôte JF, Nepveu G (2002) Choosing simplified mixed models for simulations when data have a complex hierarchical organization. An example with some basic properties in Sessile oak wood (Quercus petraea). Ann For Sci 59(8):847-856

Littell RC, Milliken GA, Stroup WW, Wolfinger RD (1996) SAS system for mixed models. SAS Institute, Cary

Mosedale JR, Charrier B, Janin G (1996) Genetic control of wood colour, density and heartwood ellagitanin concentration in European oak (Quercus petraea and Q. robur). Forestry 69: 111-124

SCEES (1996) Forests and the wood and timber industries. Collection GraphAgri Forêt-Bois, p 150

Snakkers G, Nepveu G, Guilley E, Cantagrel R (2000) Variabilités géographique, sylvicole et individuelle de la teneur en extractibles de chênes sessiles français (Quercus petraea Liebl.): polyphénols, octalactones et phénols volatils. Ann For Sci 57:251-260

Srinivasan U, Ung T, Taylor A, Cooper PA (1999) Natural durability and waterborne preservative treatability of Tamarack. Forest Prod J 49(1):82-87

Tsoumi G (1991) Structure, Properties, Utilization. In: Reinhold, V. N. (Ed.) Science and Technology of Wood. pp 494, New York

Viitanen H, Paajanen L, Saranpää P, Viitaniemi P (1997) Durability of larch (Larix spp) wood against brown-rot fungi. International Research Group on Wood Preservation, Document No IRG/WP/97-10228, p 8

Viitanen H, Paajanen L, Nikkanen T, Velling P (1998) Decay of Siberian larch wood against brown rot fungi. Part 2. The effect of genetic variation. International Research Group on Wood Preservation, Document No IRG/WP/98-10287, p 7 